\title{
Modeling of kart noise spread in to the living area and assessment of mitigation measures
}

\author{
Giedrius Juozaponis, Raimondas Grubliauskas* \\ Vilnius Gediminas technical university, Sauletekio av. 11, LT-10223 Vilnius, Lithuania
}

\begin{abstract}
Kart noise spread into living area and it is mitigation measures is analysed in the article. The purpose of the work is to ant to provide effective remedies to mitigate it using the remedies for noise mitigating. The following tasks are analysed in this work: to assess the spread of karting noise into living area and to evaluate the remedies for noise mitigating using the way of modelling. The work consists of introduction, review of methodology, summary of results, conclusions and the list of used literature. The following are discussed in the introduction paragraph: the analysed problem, the actuality of work, research object, the purpose of work and tasks, methodology of research and practical reason of work results. The spread of karting noise and mitigation of it using CadnaA computer program is analysed in methodology review. The spread of noise, the effectiveness of remedies for noise mitigation and their effect for spread of noise are reviewed in the results, also modelling of remedies for noise mitigation.
\end{abstract}

Keywords: kart noise; kart noise spread in to the living area; air pollution of kart noise.

\section{Introduction}

In the recent world while the surrounding environment are in continuous modernization, the flow of transport and mechanisms are increased in living areas, the areas of noises and the level of pollution in these areas are increasing also [14].

The mostly common source of noise is transport. The various engineering mechanisms are installed in case to mitigate the noise [10].

In dependence of location, level of noise and the result we prefer to achieve it could be designed noise barriers, the noise barriers to mitigate the noise or in the architecture stage, we could choose to project special flora which would absorb the noise [2].

The plants like a filter absorb and suspend the noise. For example, sound wave with frequency $500 \mathrm{~Hz}$ after pass through trees or bushes met acoustic noise barrier and rebound about $32 \%$ of sound energy, another part $68 \%$ is absorbed because of various leaves orientation which spread the sound waves [16]. Elastic leaves mitigate the energy of sound waves. In other cases the following protective remedies could be used like speed restriction, change of pavement, etc. [9].

Karting sport is famous all over the world, but rarely we think about the spread of noise arising from this kind of sport. Usually we are not intend to think about the effect of noise to ourselves, but it is medically approved that tiring noise decrease the immunity of organism, also noise is like a chronic source of stress make effect to central nervous system and raises others health disorder [3]. $60 \mathrm{~dB}$ noise could evoke light headache, vertigo or sound in ear even as from first point of view it is felt like a light noise to hearing [15]. Vigilance, worsed memory, concentration and orientation could also be noticed during the same level of noise [7]. Being the longer time in noisy environment our efficiency, movement coordination is intended to decrease, also nervous and risk of injury increases [1-18].

Corresponding author: Raimondas Grubliauskas. E-mail address: raimondas.grubliauskas@vgtu.lt

http://dx.doi.org/10.3846/enviro.2014.031

(C) 2014 The Authors. Published by VGTU Press. This is an open-access article distributed under the terms of the Creative Commons Attribution License, which permits unrestricted use, distribution, and reproduction in any medium, provided the original author and source are credited. 
The sources of noise which are analysed in this work are karting car, karting area, sport area for kartings, kartings competition, round routes of kartings competition and other routes which applies to sport of karting.

It is important to draw attention to the living areas close to kartings and noise pollution which is spread into these areas.

In case to apply effective remedies to decrease the noise, we have deeply evaluate current features of noise. Especially it is important Digital modelling of noise spread which will assist us in evaluating topographic, meteorological area conditions, traffic characteristics [4].

We will be looking for the ways to mitigate the noise through the choice of noise mitigation remedies after evaluation of noise spread into living areas as from karting area.

\section{Methodology}

One of the easiest way to evaluate acoustic pollution of environment is to measure the sound pressure levels of environmental noise. Hereinafter adaptation of measure methodology are quite narrow, and difficult to forecast looking into changes in future either trying to establish optimal remedies for noise spread mitigation [8].

One of the most modern computer program is CadnaA designed for modelling and forecasting noise spread.

This is the program designed to calculate and demonstrate, evaluate and forecast noise spread arising from fixed and mobile sources.

The analysed object is karting area Plytinè.

There is a need to enter the main data, route path, the closest buildings, relief, noise characteristics arising from sources in case to model the spread of karting noise [17].

The model is composed to evaluate trends of noise spread and to mitigate noise levels in living areas using mitigation remedies for noise.

The composed model reflects the current situation (Fig. 1a). The variations of noise spread are noticed later after changes of condition.

The map including objects at scale 1:4000 (Fig. 1b) (like buildings, streets, route of karting, etc.) is inserted into CadnaA program.

The main geometrical parameters are also included. The height of housing and other buildings fluctuates from 3 to 15 metres in the analysed territory.

The buildings located in the area of karting's noise are below compare to source of noise (karting).

The route of karting is limited to escarp, wood which height is 26 metres. Relief is divided into two areas: karting area is located in higher place isoline +20 , living area is in below area isoline is +10 , therefore the values of relief is an important parametre to evaluate spread of noise.

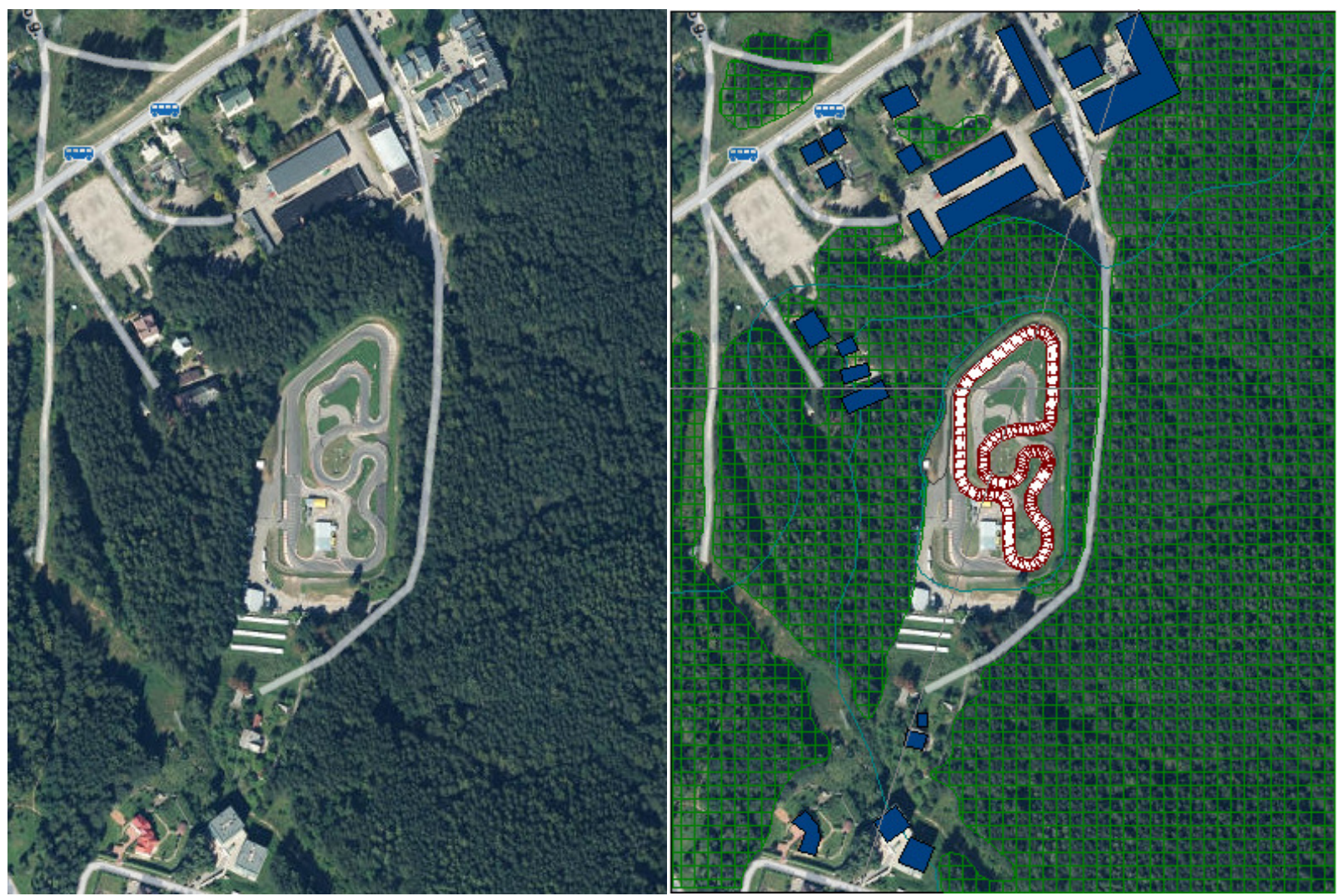

Fig. 1. The view of analysed territory: a) current situation; b) the view in modelling program:

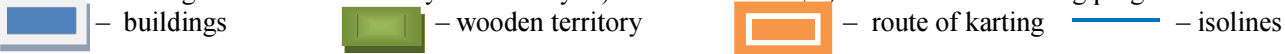




\section{Results}

The spread of noise in the territory of karting is modelling by program "CadnaA". In case to evaluate the spread of karting noise into living area, objects located in the karting territory are included in the program. Also the level of noise is measured in the territory. The spread of noise into living area is presented in the Fig 2. Also noise spread is presented in the vertical layer in Figures 2a, 2b.

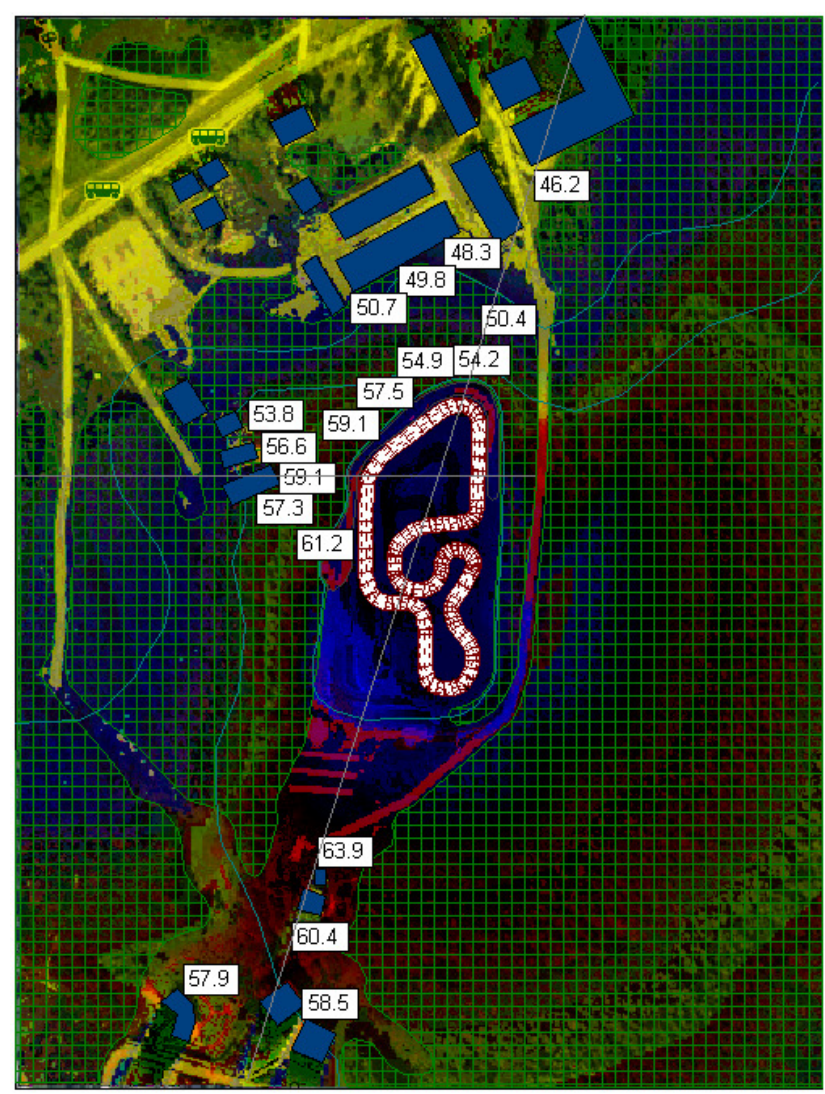

Fig. 2. Distribution of noise spread in living area:

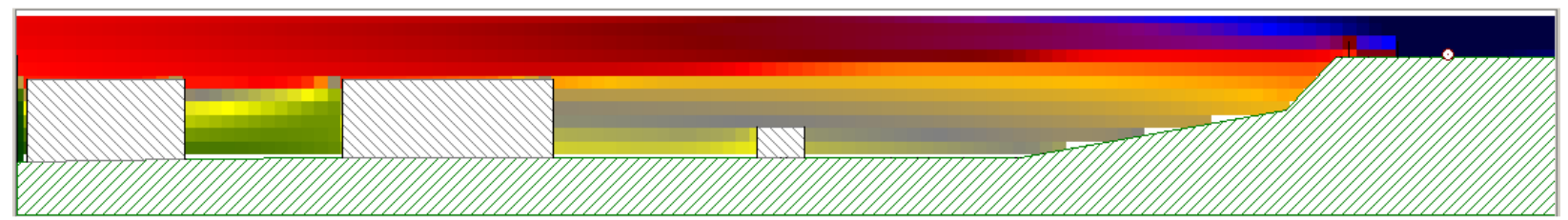

a - Vertical layer in the upper part of karting;

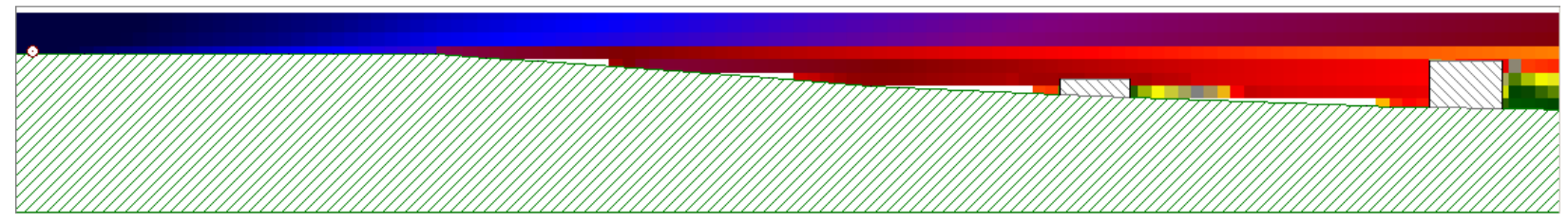

b - Vertical layer in the lower part of karting;

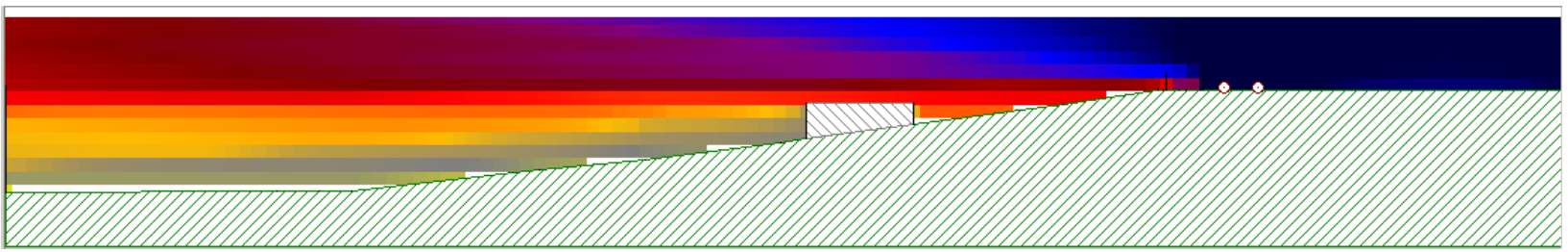

$\mathrm{c}-$ Vertical layer in the left part of karting 
We can notify as from results in the model, that living territories located in the left lower part of karting are effected by higher then allowed spread of noise. This is because of the noise which does not met the repressed objects on it's way or these objects do not hold relevant characteristics.

Following the Lithuanian Hygiene Standard HN 33:2011 "Marginal values of noise in living and public buildings and in their environment" the allowable level of noise is $55 \mathrm{~dB}$ [5]

The remedies for noise mitigation is chosen using the program functions. The escarp with a height of $3 \mathrm{~m}$ is banked currently in the upper part of karting route. The effect of this escarp is visible after modelling of noise spread without escarp. The results are presented in the Fig. 3.



Fig. 3. Distribution of noise spread in the upper part of kartign after removal of escarp

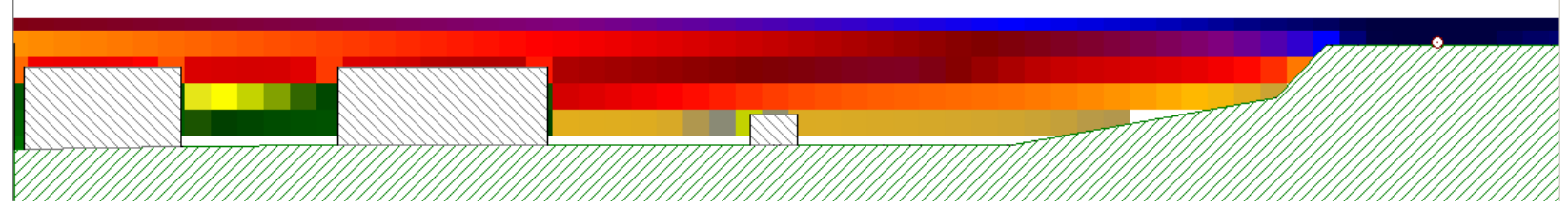

a - Vertical layer in the upper part of karting; 


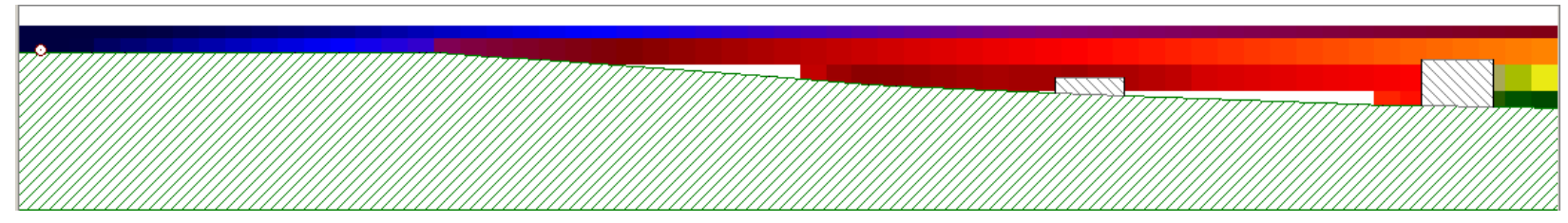

b - Vertical layer in the lower part of karting;

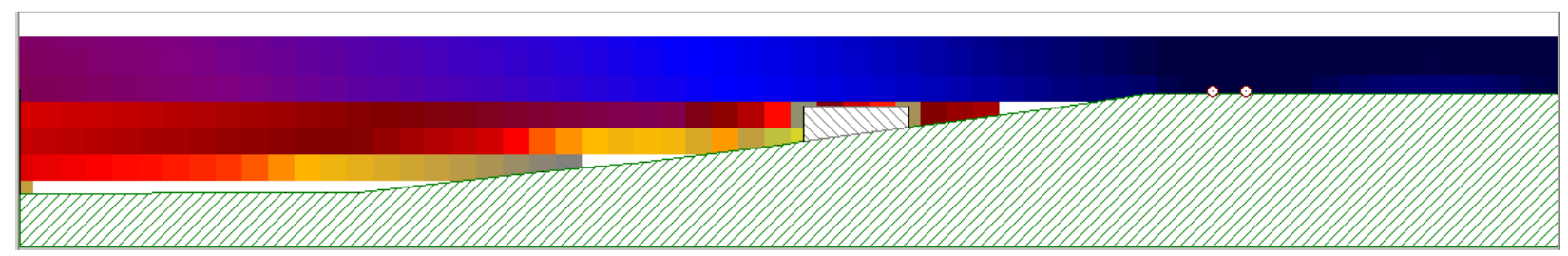

c-. Vertical layer in the left part of karting

It is visible that escarp has a definite effect for spread of noise. If without the escarp in the upper part of karting, the level of noise increases up to $5 \mathrm{~dB}$.

After evaluation of some tests through change of escarp height and parameters and shapes of suppression noise barrier, it was decided to design the suppression noise barrier with height $10 \mathrm{~m}$ in the left part of karting and $5 \mathrm{~m}$ suppression noise barrier in the lower part of territory. The results achieved are presented in the Figs 4, 4a, 4b, 4c.

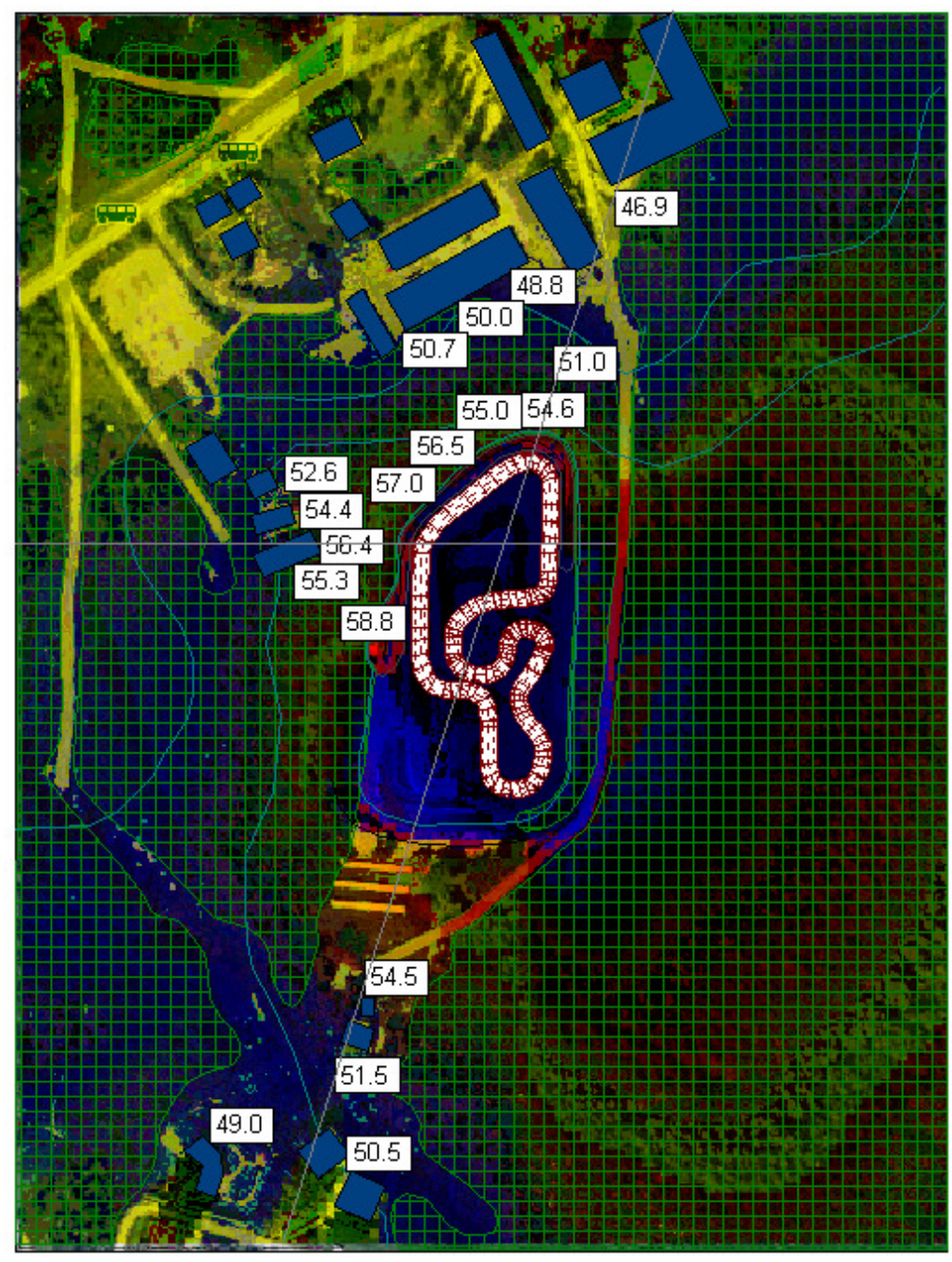

Fig. 4. Distribution of noise spread after the designing of noise barrier suppress: 




a - Vertical layer in the upper part of karting;

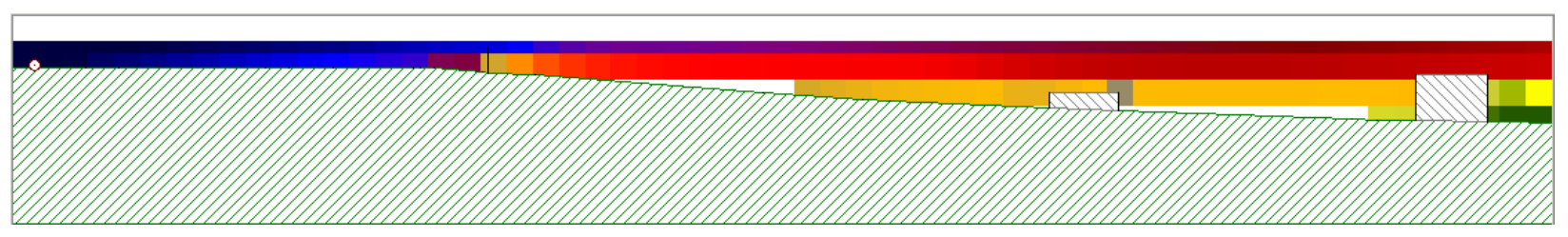

b - Vertical layer in the lower part of karting;

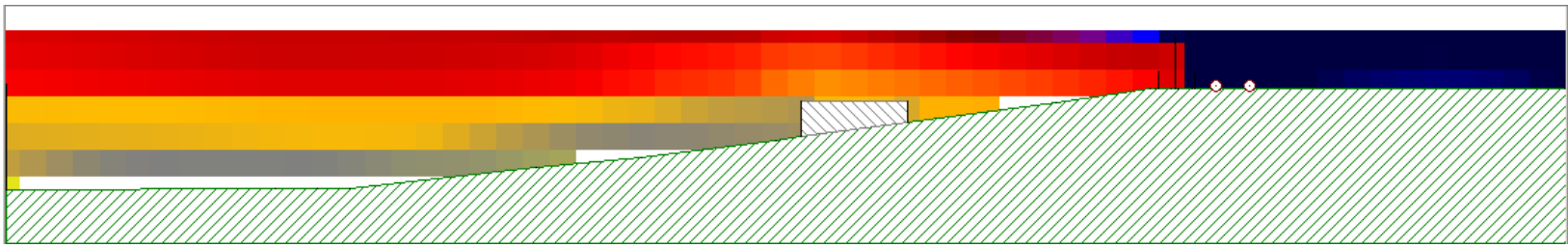

$\mathrm{c}-$ Vertical layer in the left part of karting

It is visible that noise was decreased up to standards after choice of suppression noise barriers. There many remedies to mitigate the noise, like designing the reliefs (escarps, subgrades), suppression noise barriers for noise (reflecting, absorbing the noise), screens for noise suppression and etc. It is important that remedy chosen for noise mitigation would be not only effective but also optimal choice in estetic, architectural and economical way [11],[12].

The effectiveness of remedies for noise mitigation is comparable in Table 1.

Table 1. The effectiveness of remedies for noise mitigation

\begin{tabular}{llll}
\hline & $\begin{array}{l}\text { Distribution of noise spread without } \\
\text { embankment }\end{array}$ & $\begin{array}{l}\text { Distribution of noise spread with } \\
\text { embankment }\end{array}$ & $\begin{array}{l}\text { Distribution of noise spread with } \\
\text { noise barrier }\end{array}$ \\
\hline $\begin{array}{l}\text { The level of noise behind } 10 \mathrm{~m} \text { out } \\
\text { of karting }\end{array}$ & $79,2 \mathrm{~dB}$ & $61,1 \mathrm{~dB}$ & $58,8 \mathrm{~dB}$ \\
$\begin{array}{l}\text { The level of noise behind } 50 \mathrm{~m} \text { out } \\
\text { of karting }\end{array}$ & $63,6 \mathrm{~dB}$ & $57,3 \mathrm{~dB}$ & $55,3 \mathrm{~dB}$ \\
$\begin{array}{l}\text { The level of noise behind } 100 \mathrm{~m} \text { out } \\
\text { of karting }\end{array}$ & $52,4 \mathrm{~dB}$ & $49,8 \mathrm{~dB}$ & $50,0 \mathrm{~dB}$ \\
$\begin{array}{l}\text { The level of noise behind } 150 \mathrm{~m} \text { out } \\
\text { of karting }\end{array}$ & $50,9 \mathrm{~dB}$ & $46,2 \mathrm{~dB}$ & $46,9 \mathrm{~dB}$ \\
$\begin{array}{l}\text { The level of noise behind } 200 \mathrm{~m} \text { out } \\
\text { of karting }\end{array}$ & $60,2 \mathrm{~dB}$ & $60,2 \mathrm{~dB}$ & $51,5 \mathrm{~dB}$
\end{tabular}

It is visible from 1 Table, that spread of noise by distance of $10 \mathrm{~m}$ is not blocked neither the noise barrier, not the embankment and spread was even with the difference of $20 \mathrm{~dB}$. The difference decrease to $9 \mathrm{~dB}$ after comparing the spread if noise into living area with the distance of 50m. The difference of noise spread by distance $100 \mathrm{~m}$ in karting area between with and without remedies for mitigation is $3 \mathrm{~dB}$. There is no effect of escarp because $200 \mathrm{~m}$ spread of noise was evaluated in the lower part of karting of living territory. The embankment is banked in the upper part of karting.

The remedies for mitigation of noise spread simply is chosen using the model for spread of noise as from sources into living areas created by modelling way. The results achieved differs as from actual results about $15 \%$, but this is allowable as it is not evaluated all factors which effects spread using modelling in "CadnaA" program.

\section{Conclusions}

1. The remedies for mitigation of noise spread simply is chosen using the CadnaA model for spread of noise into living areas. 
2. Noise spread by distance of $10 \mathrm{~m}$ is not blocked neither the noise barrier, not the embankment and spread even with the difference of $20 \mathrm{~dB}$.

3. The difference decrease to $9 \mathrm{~dB}$ after comparing the spread if noise into living area with the distance of $50 \mathrm{~m}$.

4. The difference of noise spread by distance $100 \mathrm{~m}$ in karting area between with and without remedies for mitigation is $3 \mathrm{~dB}$.

5. There is no effect of escarp because $200 \mathrm{~m}$ spread of noise was evaluated in the lower part of karting of living territory. The escarp is banked in the upper part of karting.

\section{References}

[1] Baltrènas, P. ir kt. 2008. Aplinkos apsauga. Vilnius: Technika.

[2] Kaulakys, J. 1999. Fizine technologine aplinkos tarša. Triukšmas ir vibracija. Vilnius: Technika.

[3] Baltrukonis, J. 1997. Ekologija tavo namuose. Kaunas: 150 p.

[4] NDT išteklių centras http://www.ndt-ed.org/index_flash.htm.

[5] HN 33:2011 "Triukšmo ribiniai dydžiai gyvenamuosiuose ir visuomeninès paskirties pastatuose bei jų aplinkoje" Valstybės žinios, 2011-06-21

[6] ISO/CD 11819-2: 2000. "Acoustics - Measurement of the influence of road surfaces on traffic noise - Part 2: The close-proximity method." 2000.

[7] Personal communication with Paul Donavan, Illingworth \& Rodkin, Inc. April 2009.

[8] Acoustic performance. Low noise road pavements. Danish Road Institute/Road Directorate, Technical Note 44, 2006. See: www.roadinstitute.dk

[9] Further Development of the Sound Intensity Method of Measuring Tire Noise Performance of In-Situ Pavements. Illingworth \& Rodkin, Inc. Report prepared for the California Department of Transportation January 4, 2006. See: http://www.i80.dot.ca.gov/hq/env/noise/pub/2 Probe_SI_Report_04Jan06.pdf.

[10] Optimized thin layers - urban roads - the Kastrupvej experiment. Danish Road Institute/Road Directorate, Technical Note 66, 2008. See: www.roadinstitute.dk

[11] Volpe Center Updates on Tire/Pavement Noise Studies. Judith L. Rochat. U.S. DOT, Volpe Center Acoustics Facility. Presentation at TRB ADC40 Summer Meeting San Luis Obispo, CA. July 2007. See: http://www.adc40.org/summer2007/22\%20JRochat_TRB\%20July\%20 2007.pdf

[12] Comparative Measurements of Tire/Pavement Noise in Europe and the United States. Noise Intensity Testing in Europe (NITE) Study. State of California Department of Transportation. Paul R. Donavan, Illingworth \& Rodkin, Inc. July 26, 2006. A summary can be found at: http://www.dot.ca.gov/hq/env/noise/pub/NITE_Article for_Caltrans.pdf

[13] Promosportas http://www.promosportas.lt/

[14] Klibavičius, A. 2008. Transporto neigiamo poveikio aplinkai vertinimas. Vilnius: Technika

[15] Mačiūnas E.; Juozulynas A.; Genytė L. 1999. Triukšmo įtaka žmonių sergamumui, Sveikatos aplinka 3: 46-48.

[16] Černiauskas, S. Akustinis triukšmas. [Žiūrèta 2007 m. sausio 14 d.]. Prieiga per internetą: http://www.kvsc.lt/06_archyvas/sveik_aplinka/akustinis_triukšmas.htm

[17] Steponaitis, L. 2007. Akustinès medžiagų savybès, jų naudojimas statybinèse konstrukcijose, iš 10-osios Lietuvos jaunujų mokslininkų konferencijos „Mokslas - Lietuvos ateitis“, ivykusios Vilniuje 2007 m. kovo 29-30 d., pranešimų medžiagos: Statyba. Vilnius: Technika, 108-113

[18] Pilipavičiūtè, J.; Bakas, A. 1998. Transporto taršos neigiama itaka gyvenamajai aplinkai, Aplinkos apsaugos inžinerija. Vilnius: Technika, p. 133-138. 